SHORT NOTE

\title{
Cylindrospermopsis raciborskii (Nostocales, Cyanobacteria): A brief historic overview and recent discovery in the Assiniboine River (Canada)
}

\author{
Hedy J. KLING \\ Algal Taxonomy and Ecology Inc. 31 Laval Drive, Winnipeg, Manitoba, R3T 2X8 Canada; e-mail: hkling@mts. \\ net
}

\begin{abstract}
Cylindrospermopsis raciborskii (WoŁoszyńSKa) Seenayya et Subba Raju is a freshwater planktonic nitrogen fixing filamentous toxic cyanobacterium (blue-green alga, cyanoprokaryote) belonging to the order Nostocales. Historically, it was thought to be a tropical or subtropical alga but in the past 26 years since it was recorded in Hungary in 1978, it has been found in increasing abundance in rivers and shallow water bodies in temperate regions of Asia, Africa, Australia, Europe, North America and South America by several researchers including most recently Branco \& Senna (1991), Padisák (1997), Chapman \& Schelske (1997), Fabbro et al. (1996), DVOŘÁK \& HAŠLER (2007). KoMÁREK \& KOMÁRKOvÁ (2003) give a comprehensive summary of the nomenclature changes, phenotypic plasticity and historic distribution record to 2002. KомÁREK \& KoмÁrKovÁ (2003) note the first European record was by SKUJA in his 1937 documentation of Greek and middle Asian algae.
\end{abstract}

Key words: Cylindrospermposis raciborskii, Assiniboine River Canada, new record

\section{Introduction}

In North America in the late 1990s Cylindrospermopsis raciborskii was recorded in many Florida lakes and rivers (CHAPMAN \& SCHELSKE 1997). Since then and it has been found in many of the central and eastern United States (ST. Amand 2002) most likely due to increased levels of water quality monitoring. In the older literature, there are drawings of what appear to be this species reported as Anabaenopsis raciborskii, from lakes near Minneapolis in the late 1960s (HILL 1970) and another by TAFT \& TAFT (1971) from Lake Erie during the intense monitoring and eutrophic stages of this lake in the 1970s. However, the earliest record in North America is probably PRESCOTT \& ANDREWs (1955) from Kansas where it was recorded as Anabaenopsis seriata. The alga has therefore been in central North America, in south central temperate water bodies with suitable environmental conditions, longer than the numerous recent mid 90's records imply. In many places it went and will go unnoticed, since it does not form a noticeable surface water bloom but remains suspended in the water column and because water quality monitoring program are insufficiently comprehensive enough to pick it up. Cylindrospermopsis raciborksii has been recorded as rapidly expanding in some geographical areas and is regarded as an invasive species. The increased frequency of its occurrence is not so much a recent invasion as it is the result of improved water quality monitoring, the availability of suitable habitat through climate warming and eutrophication and its adaptability. In some cases its presence may be ephemeral, in that it may flourish only when optimum conditions occur in turbid rivers, shallow lakes or reservoirs.

The species appears eutrophic to hypertrophic, preferring light limited environments with temperatures ranging from 20 to $35^{\circ} \mathrm{C}$ but it can tolerate a wide range of both light and temperature. It also has a high uptake rate and storage capacity for phosphorus (SHAFIK et al. 2000) with the capacity to obtain all the nitrogen it needs from the atmospheric nitrogen fixation. It is very adaptable and can tolerate higher light conditions and lower temperatures by increasing its production of polyunsaturated fatty acids (VARKONYI et al. 2000). It is important from a water quality perspective because the majority of strains can produce the alkaloid cytotoxin (a hepatotoxin) cylindrospermopsin which has been implicated in human and animal poisonings in various parts of the world (CARMICHAEL et al. 2001, Chorus \& BARTRAM 1999, and other authors). In Australia abundances as low as 15000 cells.ml $^{-1}$ have resulted in positive Cylindrospermopsis in tests while 20000 cells. $\mathrm{ml}^{-1}$ regularly produced as much as 1 ug. $\mathrm{l}^{-1}$ Cylindrospermopsis (MCGREGOR 
\& FABBRO 2000). In addition some strains have been found to produce paralytic shellfish poisoning (PSP) toxins (NeILAN et al. 2003). The levels found at the sites in the Assiniboine River were $<100$ cells. $\mathrm{ml}^{-1}$ and therefore nowhere near a threat at this point in time.

Morphotypes of Cylindrospermopsis raciborskii specimens were identified from water samples received (see acknowledgements) from 2 stations on the Assiniboine River August 31, 2004 and September 3, 2004 between Portage la Prairie and Headingley, Manitoba, Canada. Trichomes were mainly straight or slightly arcuated, very rarely flexuous, heterocysts oval or ovoid, rounded at the tapering end, cells 2.5-7 x 1.7-2.8 $\mu \mathrm{m}$ (often difficult to discern), within the range and variability noted by KOMÁREK \& KoMÁRKOVÁ (2003) and similar to figure 1A in DVOŘÁK \& HAŠLER (2007). Morphology can vary considerably with environmental conditions (FABbro et al. 1996, KomÁRKova et al. 1999, McGREGOR \& FABbro 2000, KomárKovÁ et al. 1999). No coiled froms were found.

The presence of this species in the river during this year with its rather cooler summer is rather surprising given its ecological preferences listed above. The specimens found for the most part had heterocyt so were fixing nitrogen. They were primarily the straight form (there is a high degree of morphological variability (FABBRo et al. 1996, KomÁreK \& KomÁrKová 2003) and in the tropics akinetes or resting stages are rare but here immature akinetes were found so if they were successful in completing them it will enable them to over winter in our temperate climates. It has been reported that optimum temperatures for their akinete germination is $22-25^{\circ} \mathrm{C}$ (FABBRO \& DuivenvoODEN 1996) so given the adaptability of the organism it may or may not be able to germinate again in this river. The greatest concern is whether or not it has made it to the south basin of Lake Winnipeg. This part of the lake is shallow with frequent mixing, high nutrients especially phosphorus, light limited with high turbidity and due to its shallow nature can become quite warm. Oxbows along the rivers and other shallow lakes can reach temperature in the 20's by the end of the summer so with increase eutrophication especially phosphorus in our water supplies we are creating an ideal habitat for the invasion of this toxic adaptable species. DokULIL \& Meyer (1996) recorded it as part of a bloom in an eutrophic oxbow lake formerly part of the Old Danube
River. It is the adaptability of Cylindrospermopsis raciborskii that is most worrisome due to its potential for toxin production and its adaptable nature. Recent literature suggests it is more adaptable than originally thought. Especially, since the discovery of its presence in one area of Lake Balaton, nutrients entering the lake have been substantially reduced and the species continued to flourish and spread to other area of the lake. This is thought to be due to its extreme adaptability and the fact that it can rapidly uptake phosphorus during short term phosphorus renewal events. BRAND et al. (2004) following its recent discovery in France tried to elucidate its method of acclimation using cultures of several strains and they found that all these strains had a wide range of both temperature and light tolerance.

\section{Conclusions}

Cylindrospermospsis raciborskii is present in the vicinity of Winnipeg and seems to be well capable of adapting to the conditions currently present in some of our water bodies.

Only time and increased monitoring will allow us to know if it succeeds in acquiring a foot hold strong enough to sustain a viable perennial population.

Creating a less hospitable habitat (erosion management and phosphorus reduction) in our rivers and lakes, may prevent this toxic nitrogen fixing blue-green species from becoming a permanent problematic resident in these lakes and rivers.

On a world wide basis and the fact that many of the populations encountered produce the cyanotoxin (cylindrospermopsin) makes Cylindrospermopsis (particularly C. raciborskii) one of the most important water management challenges in recent years.

\section{Acknowledgements}

The species Cylindrospermopsis raciborskii was identified here in Manitoba from samples obtained through the Assiniboine River Monitoring Study, conducted on behalf of the City of Portage la Prairie, the Rural Municipality of Portage la Prairie, Simplot (Canada) Ltd., and Manitoba Water Services Board by North/South Consultants Inc. and Earth Tech (Canada) Inc. For more information on the Assiniboine River Monitoring Study contact Mr. Kelly Braden, Director of Operations, City of Portage la Prairie (204-2398350, e-mail: kbraden@city-plap.com). Their data will be presented in a data report for the Assiniboine 
River Monitoring Study that was to be submitted in November 2004. * The views and opinions expressed herein are those of the author and do not necessarily represent those of either the City of Portage la Prairie or North/South Consultants Inc.

\section{References}

Branco, C.W.C \& Senna, P.A.C. (1991): The taxonomic elucidation of the Paranoa Lake (Brasiflia, Brazil) problem: Cylindrospermopsis raciborksii. - Bull. Jard. Bot. Nat. Belg. 61:8591.

Brand, J.F., Leboulanger, C., Hambert, J.F., Bernard, C. \& Dufour, P. (2004): Cylindrospermopsis raciborskii (Cyanobacteria) invasion at mid-latitudes: selection, wide physiological tolerance, or global warming. - J. Phycol. 40: 231-238.

Carmichael, W.W.,Azevedi, S.M. F.O, An, J.S., Molica, R.J.R., Jochimsen, E.M., LaU, S., Rinehart, K.L., Shaw, G.R. \& Eaglesham, G.K. (2001): Human fatalities from cyanobacteria: chemical and biological evidence for cyanotoxins.Environ. Health Perspect. 109:663-668.

DVořÁK, P. \& HAŠLER P. (2007): Occurrence and morphologicalvariability of Cylindrospermopsis racibirskii near Olomouc in 2006. - Fottea 7: 39-42.

Chapman, A.D. \& Schelske, C.L. (1997): Recent Appearance of Cylindrospermopsis (Cyanobacteria) in five hypertrophic Florida Lakes. - J. Phycol. 33: 191-195.

Chorus, I. \& Bartram, J. (eds) (in press.): Toxic Cyanobacteria in Water: A. Guide to their Public Health Consequences, Monitoring and Management. - 416 pp., E. \& FN Spon, London, World Health Organization, Geneva.

FABBro, L.D. KLING, H.J. \& DuivenVOORDEN, L.J. (1996): Morphological variation of Cylindrospermopsis in natural populations. - In: Proceedings of Cylindrospermopsis. - A new toxic algal bloom challenge for Australia, Agriculturel and Resource Management Council of Australia and New Zealand, Brisbane, Australia.

Fabbro, L.D. \& Duivenvoorden, L.J. (1996): Profile of a bloom of the cyanobacterium Cylindrospermopsis raciborskii (Woloszynska) Seenayya and Subba Raji in the Fitzroy River in tropical central Queensland. - Mar. Freshwater Res. 67: 685-694.

Komárek, J. \& Komárková, J. (2003): Phenotype diversty of the cyanoprokaryotic genus Cylindrospermopsis ( Nostocales): review 2002 - Czech Phycology 3:1-30.

KomÁrková, J., LaudAres-Silva, R \& Senna, P.A.C. (1999): Extreme morphology of
Cylindrospermopsis raciborskii (Nostocales, Cyanobacteria) in the Lagoe de Peri, a freshwater coastal lagoon, Santa Catarina, Brazil. - Algological Studies 94: 207-222.

HıLl, H.(1970): Anabaenopsis raciborskii Woloszynska in Minnesota lakes. - Minnesota Academy of Science 36: 80-82.

Mcgregor, G.B. \& FABbro, L.D. (2000): Dominance of Cylindrospermopsis raciborskii (Nostocales, Cyanoprokaryota) in Queensland tropical and subtropical reservoirs. Implications for monitoring and management. - Lakes and Reservoirs: Research and Management 5: 195205.

Neilan, B. A., Saker, M.L., Fastner, J., Törökné A. \& Burns, B.P. (2003): Phylogeography of the invasive cyanobacterium Cylindrospermopsis raciborskii. - Mol. Ecol. 12: 133-140.

PADISÁK, J. (1997): Cylindrospermopsis raciborskii (Woloszyńska) Seenayya et Subba Raju, an expanding, highly adaptive cyanobacterium: world wide distribution and review of its ecology. - Arch. Hydrobiol. 107: 563-593.

Prescott, G.W. \& Andrews T.F. (1955): A new species of Anabaenopsis in a Kansas Lake with notes on Limnology. - Hydrobiologia 7:60-63.

Shafik, H.M., Presing, M. \& Juhos, S. (2000): Growth and phosphate uptake kinetics of the cyanobacterium, Cylindrospermopsis raciborskii (Cyanophyceae) in throughflow cultures. - Freshwater Biol. 43: 257-275.

St.Amand, A. (2002): Map of selected sites in the United States where Cylindrospermopsis raciborkshii has been encountered. - Lakeline 22: pages.

TAFT, C.E. \& TAFT C.W. (1971): Algae of Western Lake Erie College of Biological Sciences. - 189 pp., Ohio State University Columbus Ohio.

VArkonyi, Z. Zsiros, O. Farkas, T. Garab, G. \& Gombos, Z (2000): The tolerance of cyanobacterium Cylindrospermopsis raciborskii to low-temperature photo-inhibition affected by the induction of polyunsaturated fatty-acid synthesis. - Biochem. Soc. Trans. 28: 892-894.

(C) Czech Phycological Society

Received October 13, 2008

Accepted November 16, 2008 